\title{
Investigation of the impact of injection timing and pressure on emissions characteristics and smoke/soot emissions in diesel engine fuelling with soybean fuel
}

\author{
Mohammed A. Fayad \\ Energy and Renewable Energies Technology Center, University of Technology-Iraq, Baghdad, Iraq \\ 11013@uotecnology.edu.iq
}

Submitted: $08 / 02 / 2020$

Revised: $\quad 14 / 04 / 2020$

Accepted: 24/04/2020

\begin{abstract}
Engine injection strategy and renewable fuel both can improve nitrogen oxides $\left(\mathrm{NO}_{\mathrm{x}}\right)$ and smoke/soot emissions in a common-rail compression ignition (CI) diesel engine. The effects of different postinjection (PI) timings (15, 30, and 45) after top dead center (aTDC) and injection pressures (550 and 650 bar) on pollutant emissions and smoke/soot emissions were investigated for combustion of a renewable fuel (soybean biodiesel). The results showed that the levels of carbon monoxide $(\mathrm{CO})$, hydrocarbons $(\mathrm{HCs})$, and $\mathrm{NO}_{\mathrm{x}}$ are reduced from the combustion of soybean biodiesel compared to the diesel fuel combustion for different injection strategy. Besides, $\mathrm{NO}_{\mathrm{X}}$ emission is clearly reduced with retarded PI timing, especially at $45^{\circ}$. It is found that the increasing injection pressure reduced gaseous emissions for both fuels. The combination between biodiesel fuel and injection strategy can provide meaningful improvements in pollutant emissions, as well as enhance the exhaust temperature compared to the diesel fuel. With biodiesel fueling, smoke/soot emissions were reduced from biodiesel combustion (by 19.7\%) under different fuel injection timings and pressures rather than from the diesel fuel combustion (by 12.2\%).
\end{abstract}

Keywords: Injection Timing; Injection Pressure; Nitrogen Oxides $\left(\mathrm{NO}_{\mathrm{x}}\right)$; Emissions; Smoke; Soot; Renewable Fuel; Diesel Engine.

\section{INTRODUCTION}

The air contamination, global warming, and fossil fuel dependency are three principal global issues; thus, they necessitate the development of advanced emission control technology and improve fuel properties. It is reported that both injection strategy and biodiesel fueling can reduce smoke level and improve engine-out emissions such total hydrocarbons (THCs) and carbon monoxide (CO) (Chen, 2014). On the contrary, it is noted in some works that nitrogen oxide $\left(\mathrm{NO}_{\mathrm{x}}\right)$ increased from the combustion of biodiesel (Hardy, 2006, McCormick, 2007), while it is reduced with postinjection due to the decline in maximum combustion temperature resulting from the late burning some of fuel in the combustion cycle (Desantes, 2007, Fayad, 2017). Multiple injection can reduce the combustion noise, smoke, and particulate matter (PM) (Fayad 2017) by controlling the injection strategies (main, pre-, and postinjection), which leads to the improvement of the characteristics of engine combustion (Nehmer, 1994, Hardy, 2006). Low-combustion temperature (LCT) is considered the main issue in most of the diesel engines (Fayad, 2018), which in turn increases the potential of PM formation and reduces the nitrogen oxides $\left(\mathrm{NO}_{\mathrm{X}}\right)$ emissions (Bobba, 2010). It is reported that the fuel postinjection increases the exhaust gas temperature (EGT) (Desantes, 2007) because of burning some of fuel in the cylinder late in the cycle, therefore, reducing the particulate emissions formation (Fayad, 2017), increasing unburned hydrocarbons (UHC), and slightly increasing fuel consumption (Yamamoto, 2006, Mohan, 2013). 
The experimental work by Ojeda et al. (Ojeda, 2009) reported that the particulate matter and smoke level are reduced with late injection more than 30 crank angle degrees (CAD). The characteristics effect of fuel postinjection (injection quantity and duration) was studied by Payri et al. (Payri, 2006) in a heavy duty diesel engine. Late fuel PI leads to increases in the exhaust gas temperature and, thus, double beneficial effect in more efficient regeneration of the diesel catalyst to oxidize and trap the PM and engine gaseous emissions (Yamamoto, 2006, Fayad, 2018). Many experimental works (Chen, 2000, Yamamoto, 2006, Mohan, 2013) have been documented in the literature on how the fuel postinjection reduces particulate emissions and improves engine performance for heavy and light engines. It is stated that jet flame from postinjection reduced the particulate emissions because of enhancing the soot oxidation from the main injection and readily oxidizing in the late of combustion cycle (Hotta, 2005). In contrast, some works have argued and showed no reduction of particulate emissions under some operating conditions (Hountalas, 2004, Desantes, 2006). In addition, it is pointed that postinjection enhanced mixing fuel/air by bringing oxygen from the main injection to inhibit the soot formation and enhance soot oxidation. The other experimental works by Dasantes et al. (Desantes, 2006) have argued that PM emissions increased with postinjection at high engine speed and load but decreased up to $50 \%$ at low and medium loads. Previous studies reported that the combustion is smokeless when the oxygen content is above 30\% in fuel-born (Miyamoto, 1998, Chen, 2008).

In recent years, stringent regulations increased on emissions combusted from fuel used especially in transportation sector (EN-590 in Europe (Standardization 2004), ASTM D 975 in USA (International 2010)), which leads to economic consequences on both price and investments of fuel companies. The attractive properties of biodiesel such as higher viscosity, cetane number, and oxygen content can improve the chemical emissions emitted from diesel engines (Sukjit, 2012, Miri, 2017). Different parameters can affect exhaust gas emissions from the combustion of renewable fuel like the quality and origin of biodiesel, ambient conditions, engine type, and engine operation conditions (speed and load). The present oxygen content in biodiesel was also reviewed by improving engine combustion resulting in lower particulate emissions, CO, THC, and smoke opacity (Bugosh, 2011, Robbins, 2011). In addition, the previous work reported that $\mathrm{NO}_{\mathrm{X}}$ emissions reduced around $50 \%$ with injecting $20 \%$ of biodiesel postinjection (Ye, 2013).

Due to the limited amount of literature reported on injection strategies and alternative fuels, the combination between injection strategies and biodiesel can provide synergistic effects to solve the potential issues that may also appear. Therefore, the purpose of this research is to investigate how soybean biodiesel fuel with injection strategy can affect emission characteristics and compare them directly with diesel fuel. This experimental work is also investigating how different postinjection angle and fuel injection pressure effect on smoke/soot emissions.

\section{EXPERIMENTAL SETUP}

\section{Engine and Instrumentation}

Engine tests were carried out with four-stroke, four-cylinder diesel engine equipped with common rail fuel injection system (main, pre-, and postinjection). Figure 1 shows the schematic diagram of experimental setup in this work. A common-rail system was used in the cylinder (see Figure 1) to control the injection events (main, pre-, and postinjection). The engine used is a four-single-cylinder direct injection (DI) diesel engine, which is water cooled, with an engine speed ranging from 900 to $2500 \mathrm{rpm}$. The main engine specifications are presented in Table 1. High fuel injection pressure was implemented into the engine research. The engine control unit (ECU) connected with sensors was used to control the fuel injection parameters (quantity, timing, and duration), which is located on the top of cam shaft and flywheel. Thermocouples (k-type) were used in different points along engine and exhaust pipe to measure the in-cylinder temperature and EGT, respectively, as well as monitoring the engine fluid temperatures. To avoid the total hydrocarbon condensation, the sampling line of equipment was heated to $190^{\circ} \mathrm{C}$. Moreover, the sample line was purged and cleaned to remove any fuel remaining or condensation inside the ample line before each test. An encoder and torque transducer were used to measure the engine speed and torque, respectively. Electrochemical gas analyzer was utilized to measure the level and concentration of engine-out emissions such as $\mathrm{CO}, \mathrm{THC}$, and $\mathrm{NO}_{\mathrm{x}}$. Additionally, the measurement of these emissions was directly recoded on the digital display screen. The level of smoke opacity was measured by using smoke meter (Hartridge MK3b) under a range of operating conditions. 


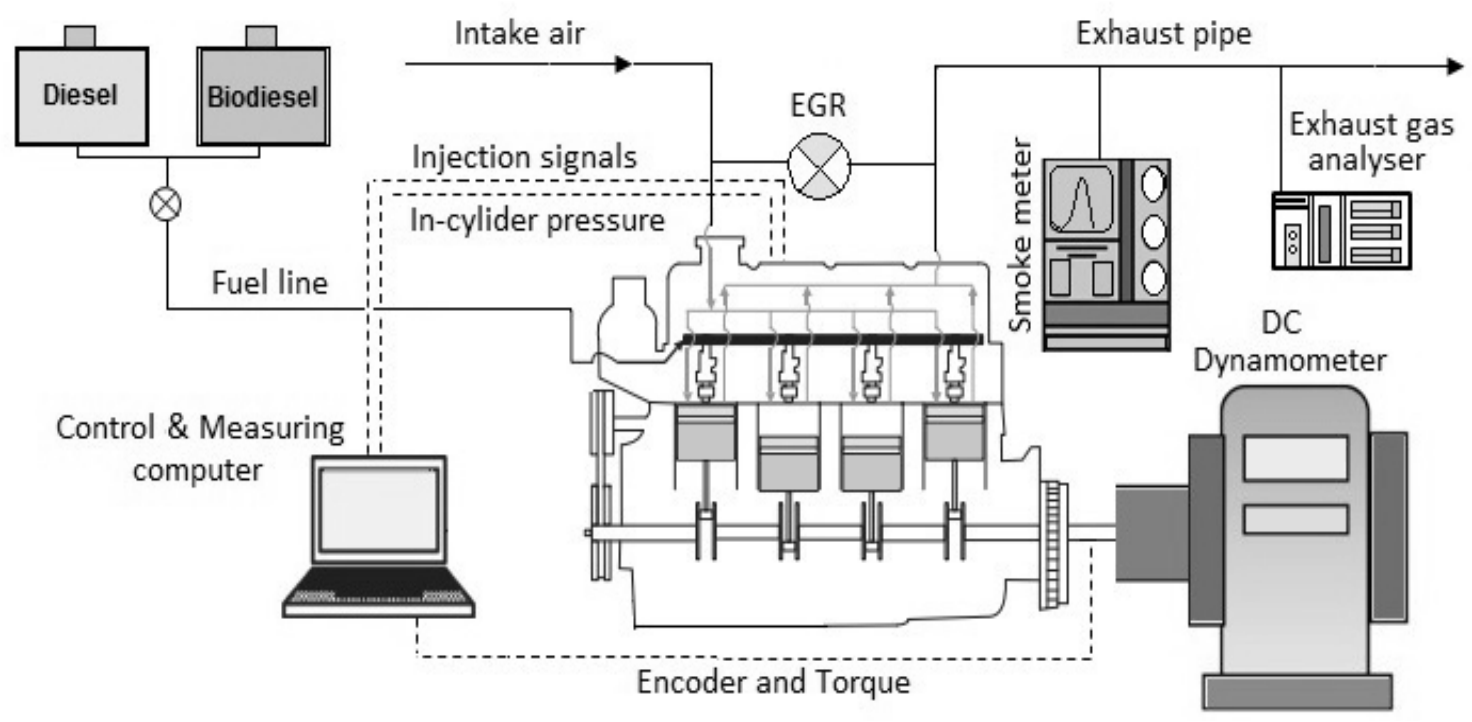

Figure 1. Schematic diagram of diesel engine and experimental setup.

Table 1. The main specifications of research diesel engine.

\begin{tabular}{|l|l|}
\hline Diesel engine parameter & Specifications \\
\hline Type & 4-Cylinder \\
Fuel injection system & Common rail injection system \\
Maximum Power & $96 \mathrm{~kW} / 2500 \mathrm{rpm}$ \\
Maximum Torque & $450 \mathrm{Nm} / 1450 \mathrm{rpm}$ \\
Bore / Stroke (mm) & $110 \times 125$ \\
Displacement (L) & 4.751 \\
Compression ratio & $17.8: 1$ \\
\hline
\end{tabular}

\section{Fuel properties}

In the experimental tests, two types of fuels were tested under different ranges of operating conditions. The diesel fuel was used as a reference fuel, and biodiesel fuel was produced from mixed feedstock of soybean. The properties (physical and chemical) of soybean biodiesel fuel can be found in Table 2 and in the literatures for various feedstocks of soybean biodiesel (Canakci, 2008, Moser, 2009). The engine was running for 20 minutes before each test to ensure cleaning any fuel remaining from the previous test. 
Table 2. Chemical and physical properties of Soybean biodiesel and diesel fuel.

\begin{tabular}{lll}
\hline Properties & Diesel & Soybean biodiesel \\
\hline Cetane Number & 53.2 & 54.7 \\
Bulk Modulus $(\mathrm{MPa})$ & 1410 & 1553 \\
Density at $15{ }^{\circ} \mathrm{C}\left(\mathrm{kg} / \mathrm{m}^{3}\right)$ & 824.1 & 883.7 \\
Kinematic Viscosity at $40{ }^{\circ} \mathrm{C}(\mathrm{cSt})$ & 2.7 & 4.53 \\
Lower Calorific Value $(\mathrm{MJ} / \mathrm{kg})$ & 42.11 & 37.8 \\
Upper heating value $(\mathrm{MJ} / \mathrm{kg})$ & 45.3 & 39.6 \\
Lubricity at $60{ }^{\circ} \mathrm{C}(\mu \mathrm{m})$ & 312 & 205 \\
$\mathrm{C}(\mathrm{wt} \%)$ & 87.24 & 76.13 \\
$\mathrm{H}(\mathrm{wt} \%)$ & 14.86 & 11.87 \\
$\mathrm{O}(\mathrm{wt} \%)$ & 0 & 10.84 \\
$\mathrm{O}$ from OH group $(\mathrm{wt} \%)$ & 0 & 0 \\
$50 \%$ Distillation $\left({ }^{\circ} \mathrm{C}\right)$ & 264 & 335 \\
$90 \%$ Distillation $\left({ }^{\circ} \mathrm{C}\right)$ & 329 & 342 \\
\hline
\end{tabular}

\section{Test procedure}

The engine starts running for half an hour without test to increase the coolant temperature to $80^{\circ} \mathrm{C}$. The indicated mean effected pressure (IMEP) was 4 bars, while the engine speed was fixed at $1800 \mathrm{rpm}$ during all experimental tests. The details of experimental test including the fuel postinjection timings for different tests are presented in Table 3 . Three fuel injection pressures are presented in Table 3. For comparative purposes, the engine was run without postinjection to give baseline results. All engine operating conditions and temperatures were monitored into a computer-controlled data acquisition and recording system.

Table 3. Details of fuel postinjection timing (PI), injection pressure, and engine conditions.

\begin{tabular}{|l|l|l|l|l|}
\hline \multicolumn{1}{|c|}{ Parameter } & \multicolumn{3}{c|}{ Value } \\
\hline Postinjection timings (CAD aTDC) & W/O & 15 & 30 & 45 \\
\hline Fuel injection pressure (bar) & \multicolumn{3}{c|}{$550 / 650$} \\
\hline Engine speed (rpm) & \multicolumn{3}{|c|}{1800} \\
\hline Indicated mean effected pressure (IMEP) & \multicolumn{3}{|c|}{4} \\
\hline
\end{tabular}

\section{EXPERIMENTAL RESULTS AND DISCUSSION}

\section{Exhaust gas temperature (EGT)}

Figure 2 shows the exhaust gas temperature (EGT) for diesel fuel and biodiesel at different PI timings and injection pressures. It can be noticed that the EGT increased with retarded PI compared to that of W/O PI for both fuels. The higher heat formed at the end of combustion from fuel PI could be the main reason to initiate the combustion reaction resulting increasing EGT. Furthermore, the use of biodiesel fuel can provide higher EGT compared to the diesel fuel via different fuel PI timings and injection pressures. This is due to the better combustion characteristics from the combustion of biodiesel. The high exhaust temperature in modern diesel engine could be helpful for passive and 
active diesel particulate filter (DPF) regeneration. The increment in EGT was observed with late injection timing (45 aTDC) as shown in Figure 2. It is reported in previous works (Wu, 2018; Fayad, 2018) that late-cycle postinjection is one of the ways to increase the exhaust gas temperature (EGT). Limited changes in exhaust temperature were noticed for both fuels without PI. The higher exhaust temperature is more clearly from the combustion of soybean biodiesel under different injection strategy conditions as shown in Figure 2. The attractive property (large amount of oxygen) in chemical composition of biodiesel leads to the improvement of the combustion temperature and enhances the EGT.

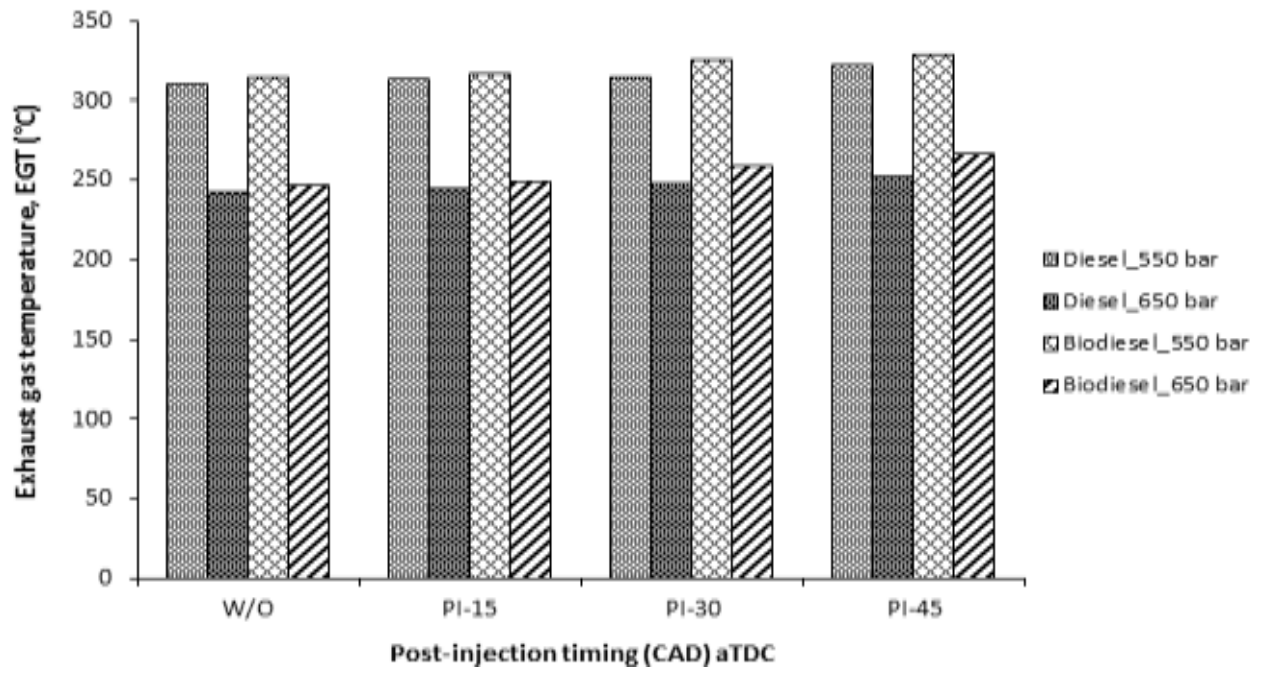

Figure 2. Effect of fuel injection strategy on exhaust gas temperature (EGT) for biodiesel and diesel fuel.

\section{Carbon monoxide (CO)}

The changes in $\mathrm{CO}$ emissions for both renewable fuel and diesel fuel under different injection timings and pressures are shown in Figure 3. The level of $\mathrm{CO}$ emissions is gradually decreasing from the combustion of biodiesel compared to the combustion of diesel fuel (Figure 3). The main reason for this is that the oxygen content of biodiesel enhances the combustion characteristics, which make more complete combustion (Rakopoulos, 2004, Sukjit, 2012). The level of $\mathrm{CO}$ emissions is reduced under baseline case W/O postinjection, while it is increased as the PI retarded, and this variation becomes clearer at $45^{\circ}$ for both fuels (Figure 3 ). This is due to the release of the heat at the later PI, leading to poor combustion, resulting in increased $\mathrm{CO}$ emissions. Furthermore, increases in $\mathrm{CO}$ emissions could be also due to the production of additional unburned $\mathrm{CO}$ emissions with late PI and absence of high enough combustion temperature for $\mathrm{CO}$ oxidation. It is reported (Chaichan, 2018) that the local heterogeneous mixture of air/fuel ration leads to incomplete combustion, thereby increasing the level of HCs (BOGARRA, 2016). In the comparison of fuels and injection strategies, the combustion of biodiesel fuel reduced the $\mathrm{CO}$ emissions for different PI injection timings and injection pressures compared to the diesel fuel combustion (Figure 3). Figure 6 shows that the early PI timing can improve and accelerate the rate oxidation of unburned emissions of CO (Fayyazbakhsh, 2016). The increase in injection pressure from 550 to 650 bars is very effective in reducing $\mathrm{CO}$ emission for both fuels as shown in Figure 3. It is reported in the literature review that the resulting high injection pressure improves combustion performance and gives better mixing as a result of easy fuel evaporation and mixing with air (Siddappa, 2007, Fayad, 2019). 


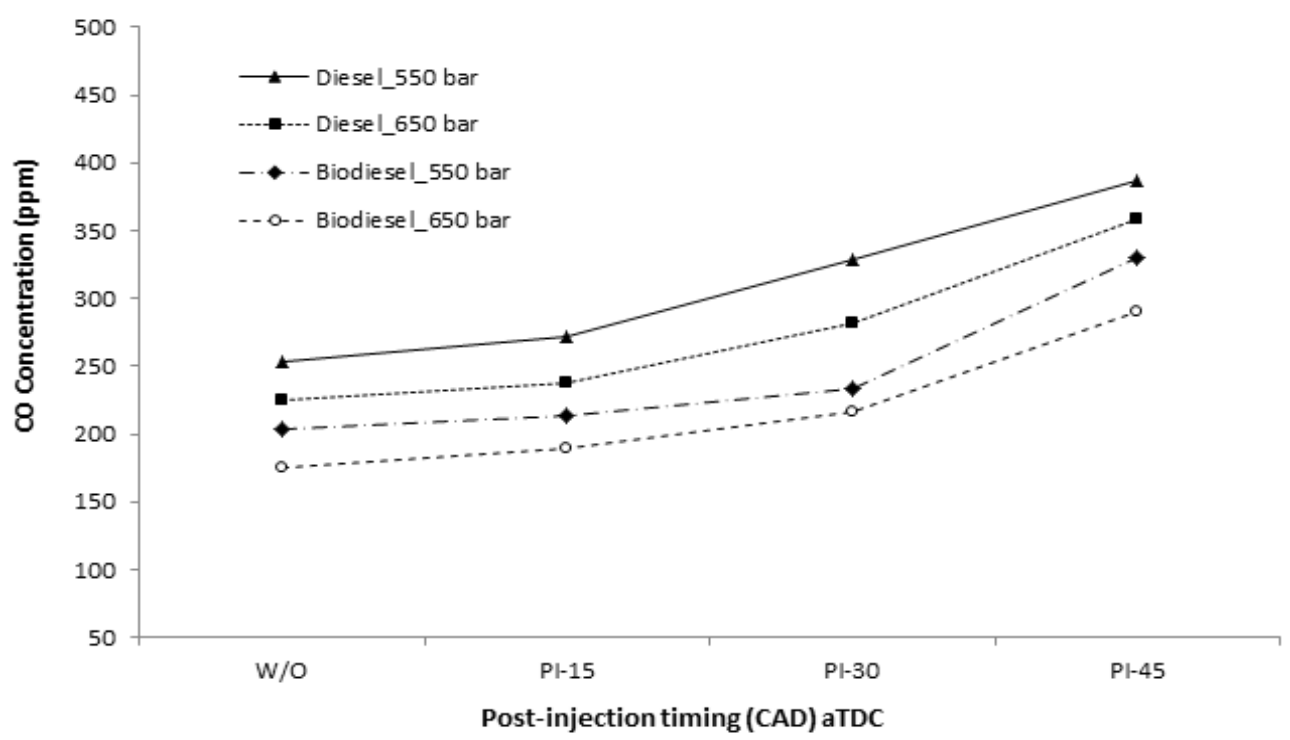

Figure 3. Effect of fuel injection strategy on CO concentration for biodiesel and diesel fuel.

The high level of $\mathrm{CO}$ and $\mathrm{HC}$ generated during the combustion of diesel fuel reduces the carbon dioxide $\left(\mathrm{CO}_{2}\right)$ concentration for various PI timings as presented in Figure 4. Interestingly, the slight reductions in $\mathrm{CO}_{2}$ concentration were $12.6 \%, 13.4 \%$, and $16.7 \%$ for $15^{\circ}, 30^{\circ}$, and $45^{\circ}$, respectively, from diesel fuel compared to biodiesel fuel (Figure 4). It can be observed that the higher concentration of $\mathrm{CO}_{2}$ emitted from biodiesel combustion indicates that the improvement in combustion is often witnessed with alternative fuels as seen in Figure 4. It can be seen that the high level of $\mathrm{CO}$ (for different PI timings) leads to reduction in $\mathrm{CO}_{2}$ with diesel fuel more when compared with biodiesel fuel (Figure 4). This could be due to the deterioration in combustion process resulting from nonhomogeneity mixture (air/fuel) (Shi, 2017, Chaichan, 2018).

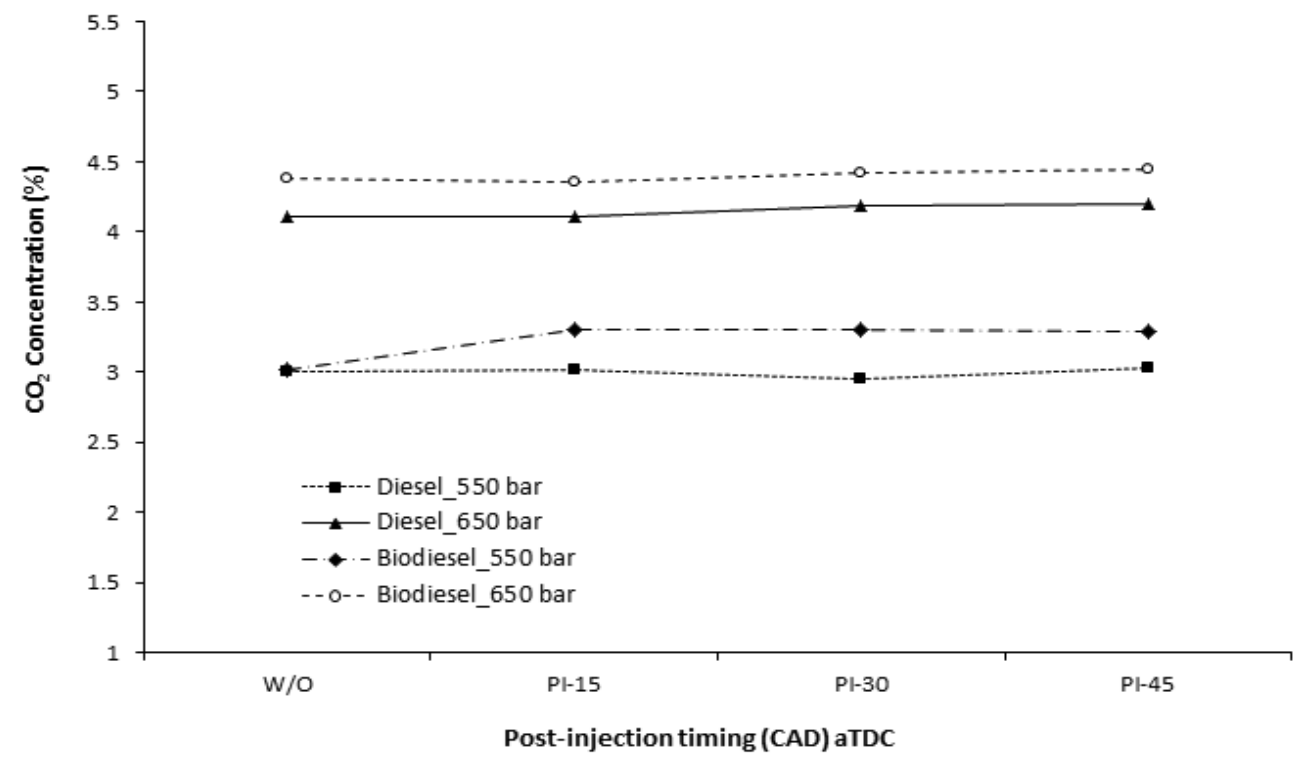

Figure 4. Effect of fuel injection strategy on carbon dioxide $\left(\mathrm{CO}_{2}\right)$ concentration for biodiesel and diesel fuel. 


\section{Light and heavy hydrocarbon $(\mathrm{HC})$}

The variations of light and heavy hydrocarbons (HC) for biodiesel and diesel fuel and different injection strategies are shown in Figure 5. It can be seen that the light and heavy $\mathrm{HC}$ were increased with retarded PI timing for biodiesel and diesel fuel. The high level of $\mathrm{HC}$ is recording at $45^{\circ} \mathrm{CAD}$ after TDC of fuel PI. This is due to incomplete combustion of fuel injected late in the combustion cycle leading to generating more unburned $\mathrm{HC}$ as presented in Figure 5. In addition, delayed PI leads to portion of the fuel being entrained to exhaust gas pipe rather than being fully combusted ( $\mathrm{Li}, 2017)$. The least $\mathrm{HC}$ emissions were found from the biodiesel combustion compared to the diesel fuel for all injection timings and pressures. This was expected because the oxygen content in biodiesel aids the performance of combustion and reduces the ignition delay. In contrast, the lower level of $\mathrm{HC}$ is produced with increasing injection pressure for the same CAD and both fuels, which are in agreement with the above results. Furthermore, the level of $\mathrm{HC}$ reduced around 17.4-38.2\% from biodiesel fuel with high injection pressure (650 bars) for the same CAD of PI timings (Figure 5). In previous studies, it is reported that the shortened period of combustion cycle is also responsible for increasing the HC emissions (d'Ambrosio, 2015, Fayad, 2015, Zheng, 2015). From both Figures (3 and 5), it can be said that the $\mathrm{HC}$ and $\mathrm{CO}$ have the same tendencies with the variation of PI (from $15^{\circ}$ to $45^{\circ}$ aTDC), and these trends were consistent with other researches (Zhang, 2007, Vanegas, 2008).

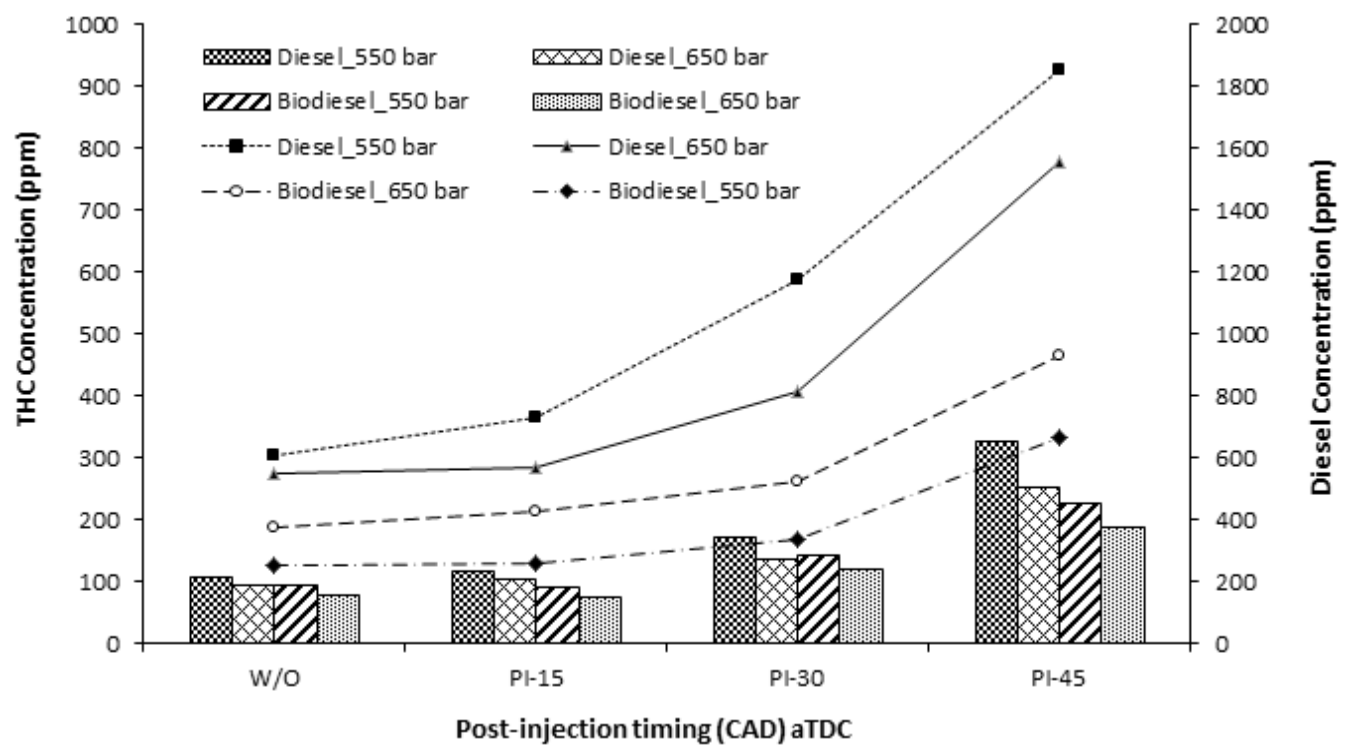

Figure 5. Effect of fuel injection strategy on the light and heave hydrocarbons (HCs) for biodiesel and diesel fuel.

\section{Oxides of nitrogen $\left(\mathrm{NO}_{X}\right)$}

The high in-cylinder temperature and equivalence ratio (Paul, 2016) during combustion process plays a vital role in the formation of $\mathrm{NO}_{\mathrm{X}}$ emissions. In addition, the availability of oxygen in the fuel properties also affects the amounts and concentration of $\mathrm{NO}_{\mathrm{X}}$ emissions (Fayad, 2020). The level of $\mathrm{NO}_{\mathrm{X}}$ emissions is higher with the absence of PI (W/O) for both fuels as shown in Figure 6. This could be because of promoting the chemical reactions between air and fuel from early main combustion phase. In contrast, the $\mathrm{NO}_{\mathrm{X}}$ emissions significantly reduced with increasing late PI (from $15^{\circ}$ to $45^{\circ} \mathrm{CAD}$ ) for diesel fuel and biodiesel. In previous studies, it is suggested that the low combustion temperature and heat transfer lead to reduction of the $\mathrm{NO}_{\mathrm{X}}$ emissions (Parlak, 2005, Sayin, 2009). Moreover, the oxygen content from the combustion of biodiesel slightly increases the $\mathrm{NO}_{\mathrm{X}}$ emissions for different injection timings and pressures compared to the diesel fuel as shown in Figure 6. The chemically bond oxygen in biodiesel leads to the increase of the potential of $\mathrm{NO}_{\mathrm{X}}$ formation (Ozsezen, 2008). According to the results, the variation of thermodynamics conditions after introducing PI could be associated with the decreases of $\mathrm{NO}_{\mathrm{X}}$ formation. The $\mathrm{NO}_{\mathrm{X}}$ emissions increased from 
high injection pressure (650 bars) for both fuels and different PI timings (Figure 6), and this trend was the same for all exhaust gas emissions. It is interesting point to see that the $\mathrm{NO}_{\mathrm{X}}$ emission reduced from renewable fuel combustion with PI timing $30^{\circ}$ and $45^{\circ}$ aTDC. This could be due to the slight reduction in the combustion temperature at the end of combustion, which leads to reduction of the $\mathrm{NO}_{\mathrm{X}}$ formation and production of moderate level of $\mathrm{NO}_{\mathrm{X}}$ emissions.

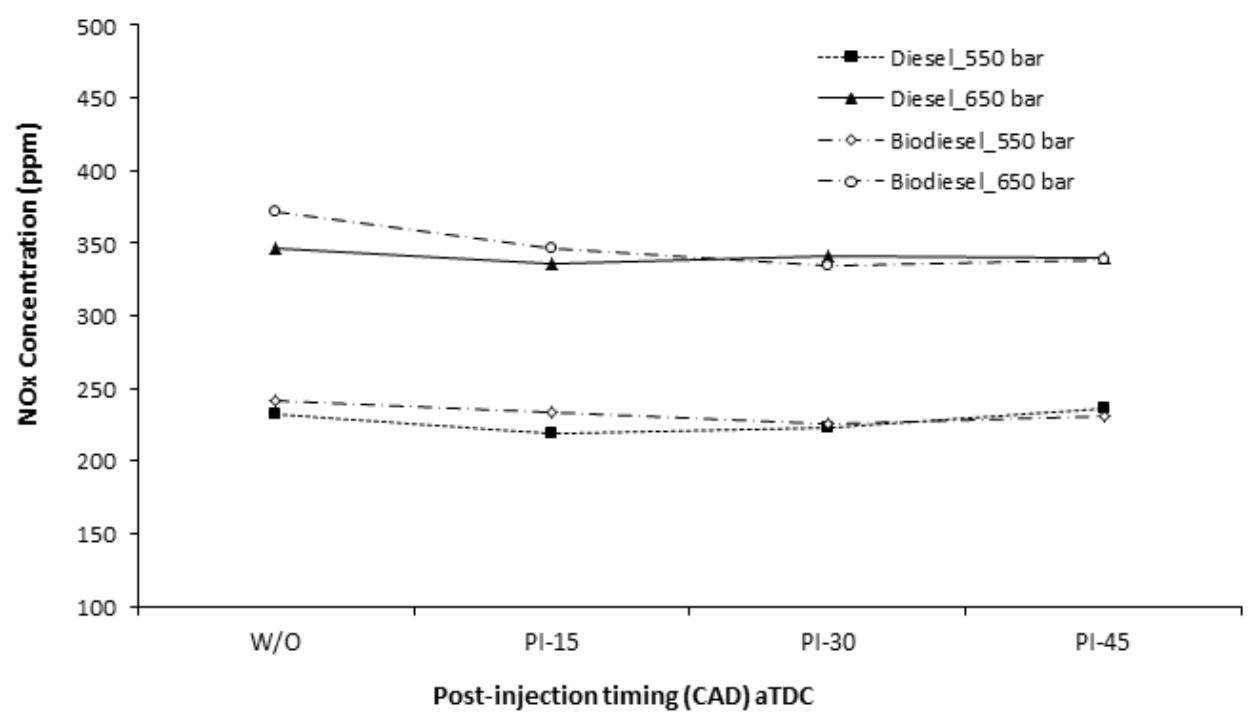

Figure 6. Effect of fuel injection strategy on the emitted $\mathrm{NO}_{\mathrm{X}}$ concentrations for biodiesel and diesel fuel.

\section{Smoke/soot emissions}

Figures 7 and 8 show the level of smoke opacity and soot emissions under different injection strategies for diesel and biodiesel. The PI technique is used to mitigate smoke/soot emissions and control the amount of $\mathrm{NO}_{\mathrm{X}}$ emissions. Three injection events allow producing lower smoke level for biodiesel and diesel fuel at different PI injection timings compared to the W/O PI (double injection). Furthermore, it is clear that the smoke opacity reduced with retarded PI, and this tendency can be noticed at $45^{\circ}$ aTDC (Figure 7). This positive effect is due to the proper oxidation of the fuelair mixture resulting from injected fuel combustion during expansion stroke.

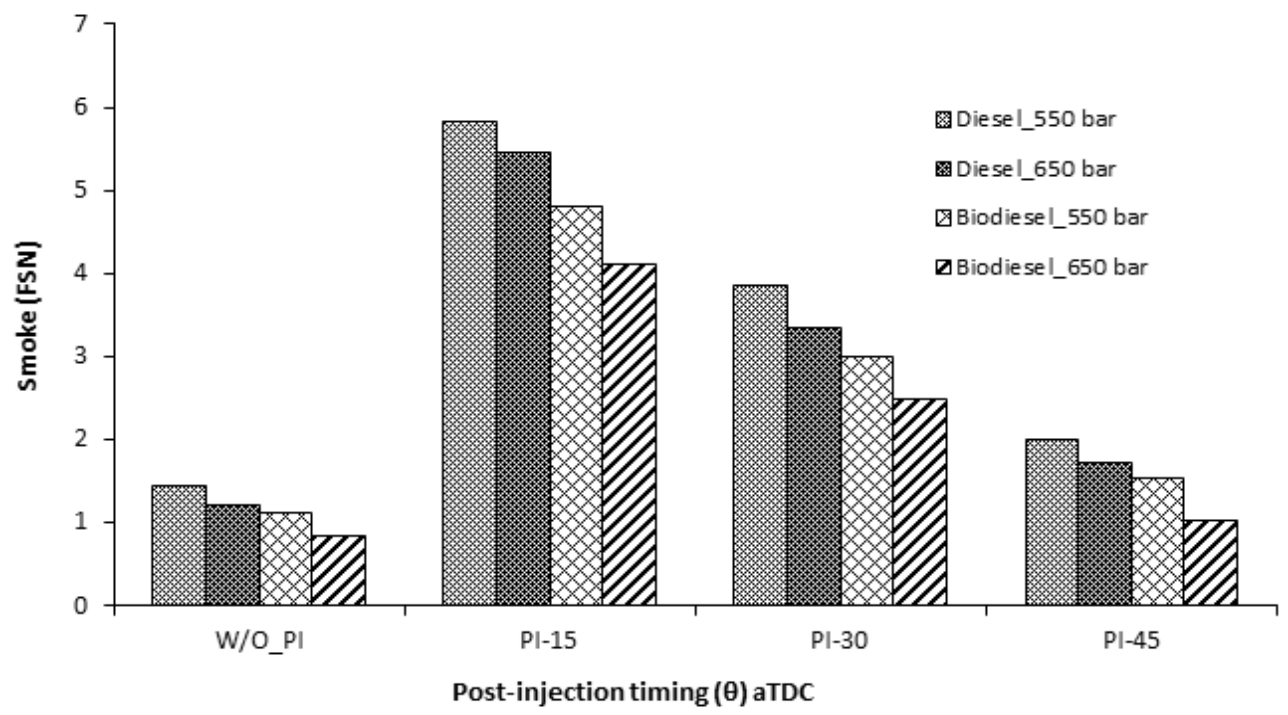

Figure 7. Effect of fuel injection strategy on the smoke opacity for biodiesel and diesel fuel. 
It can be observed that renewable fuel combustion produces lower level of soot emissions compared to that from diesel fuel combustion for different PI timings and injection pressures as presented in Figure 8. The oxygen content in fuel properties of biodiesel plays a vital role in oxidation soot particle that is already formed in combustion cycle and resulting lower level of soot. In addition, the higher exhaust temperature from biodiesel fuel can be beneficial for soot oxidation activity and reduce the soot formation during exhaust pipe when compared to the diesel fuel (Figure 8). This is largely owing to the oxygen-born and disorder degree of graphene layer structure inside soot structure from biodiesel fuel combustion (Boehman, 2005). It is documented in the literature that the biodiesel fuel is more efficient in the soot oxidation and active soot regeneration (Fayad, 2020) \{Chen, $2014 \# 29 ;$ Fayad, $2020 \# 587\}$. It is stated that the smoke/soot emissions reduced by late fuel postinjection (Hotta, 2005) and increased in-cylinder temperatures due to the combustion of the multiple injections (Fayad, 2019).

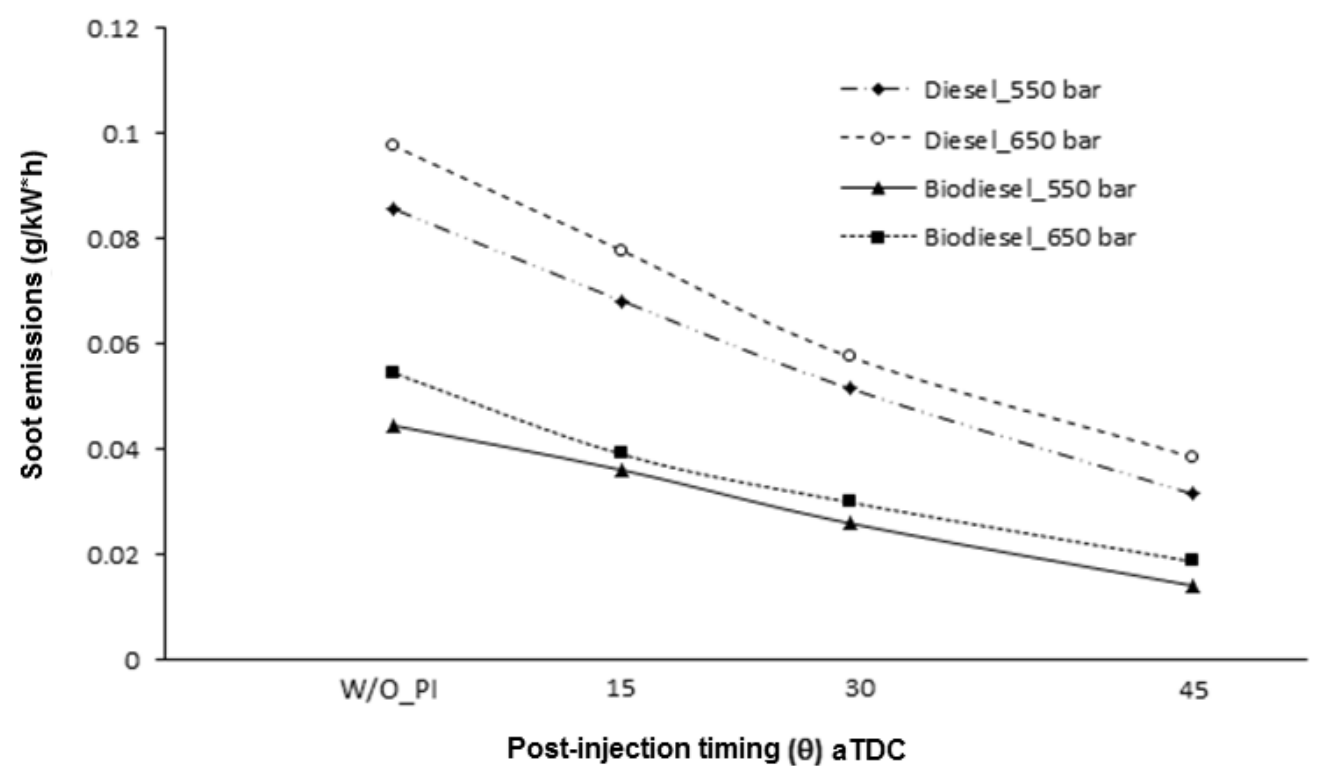

Figure 8. Effect of fuel injection strategy on the soot emissions for biodiesel and diesel fuel.

\section{CONCLUSIONS}

The emissions characteristics, exhaust gas temperature, and smoke/soot emissions have been experimentally investigated under different injection strategies (timings and pressures) for renewable fuel and diesel fuel. It can be concluded that the exhaust gas temperature increased from the combustion of biodiesel PI fuel more than that in diesel fuel, which enhances the effectiveness of environmental catalyst system. The levels of CO and THCs emissions increased by $31.3 \%$ and $38.2 \%$, respectively, with retarding PI at $45^{\circ}$ aTDC, but the $\mathrm{NO}_{\mathrm{x}}$ emissions decreased by $27.4 \%$ from biodiesel combustion. It was found that the interaction between injection strategy and biodiesel fuel caused more obvious $\mathrm{NO}_{\mathrm{X}}$ reduction (fuel mixture burned at lower temperature) compared to the diesel fuel. The results showed that the exhausted emissions were improved with increasing the injection pressure and biodiesel fueling. Furthermore, this work provides a useful insight into the effect of biodiesel fuel and injection strategy in diminishing exhaust gas emissions compared to the diesel fuel.

The level of smoke/soot emissions declined by approximately $28.4 \%$ the combustion of biodiesel because of the accessibility of oxygen required to enhance the fuel oxidation and higher temperature to oxidize the soot emissions. In addition, the smoke level and soot emissions were reduced by $11.3 \%$ and $24.1 \%$, respectively, when engine was fed with high injection pressure; thereby, it is considered a practical way to reduce the negative effect on environment. In summary, the injection strategy (timings and pressure) can be a proper technique to reduce the concern issue of smoke/ soot emissions and also boost the exhaust gas temperature. 


\section{ABBREVIATIONS}

aTDC: After top dead centre

CAD: Crank angle degrees

DPF: Diesel particulate filter

EGT: Exhaust gas temperature

PI: Postinjection

IMEP: Indicated mean effective pressure

ISFC: Indicated specific fuel consumption

$\mathrm{NO}_{\mathrm{X}}$ : Nitrous oxides (Oxides of Nitrogen)

CO: Carbon monoxide

HC: Hydrocarbon

THC: Total hydrocarbons

W/O PI: Without postinjection.

\section{ACKNOWLEDGMENT}

M.A. Fayad wishes to express thanks to the University of Technology, Iraq, for supporting this research. Thanks are due to Energy and Renewable Energies Technology Center, University of Technology, Iraq.

\section{CONFLICT OF INTERESTS}

The author confirms and declares that there is no conflict of interests regarding the publication of this paper.

\section{REFERENCES}

Bobba, M., Musculus, M., Neel, W., 2010. "Effect of post injections on in-cylinder and exhaust soot for low-temperature combustion in a heavy-duty diesel engine.” SAE International Journal of Engines, 3(1): 496-516, doi:410.4271/2010-42010612 .

Boehman, A.L., Song, J., Alam, M., 2005. "Impact of Biodiesel Blending on Biodiesel Soot and the Regeneration of Particulate Filters.” Energy Fuels 19: 1857-1864.

Bogarra, M., Doustdar, O., Fayad, M.A., Wyszynski, M.L., Tsolakis, A. Ding, P., Pacek, A., Martin, P., Overend, R., O’leary, S., 2016. "Performance of a drop-in biofuel emulsion on a single-cylinder research diesel engine." Combustion Engines, 166 ((3)): 9-16.

Bugosh, G.S., Muncrief, R.L., Harold, M.P., 2011. "Emission analysis of alternative Diesel fuels using a compression ignition benchtop engine generator.” Energy \& Fuels, 25(10): 4704-4712.

Canakci, M., Sanli, H., 2008. "Biodiesel production from various feedstocks and their effects on the fuel properties." Journal of industrial microbiology \& biotechnology, 35(5): 431-441.

Chaichan, M.T., 2018. "Performance and emission characteristics of CIE using hydrogen, biodiesel, and massive EGR." International Journal of Hydrogen Energy, 43(10): 5415-5435.

Chen, H., Wang, J., Shuai, S., Chen, W., 2008. “Study of oxygenated biomass fuel blends on a diesel engine.” Fuel, 87(15-16): 3462-3468.

Chen, P., Ibrahim, U., Wang, J., 2014. "Experimental investigation of diesel and biodiesel post injections during active diesel particulate filter regenerations." Fuel, 130: 286-295. 
Chen, S.K., 2000. Simultaneous reduction of NOx and particulate emissions by using multiple injections in a small diesel engine, SAE Technical Paper.

d'Ambrosio, S., Ferrari, A., 2015. "Potential of multiple injection strategies implementing the after shot and optimized with the design of experiments procedure to improve diesel engine emissions and performance." Applied Energy, 155: 933-946.

Desantes, J., Bermúdez, V, Pastor, JV, Fuentes, E, 2006. "Investigation of the influence of post-injection on diesel exhaust aerosol particle size distributions." Aerosol Sci. Tech. 40(1): 80-96.

Desantes, J.M., Arrègle, J., López, J.J., García, A., 2007. A comprehensive study of diesel combustion and emissions with postinjection, SAE Technical Paper.

Desantes, J.M., Bermúdez, V., Pastor, J.V., Fuentes, E., 2006. "Investigation of the influence of post-injection on diesel exhaust aerosol particle size distributions." Aerosol science and technology, 40(1): 80-96.

Fayad, M.A., 2019. "Effect of fuel injection strategy on combustion performance and NO x/smoke trade-off under a range of operating conditions for a heavy-duty DI diesel engine." SN Applied Sciences, 1(9): 1088.

Fayad, M.A., 2019. "Effect of renewable fuel and injection strategies on combustion characteristics and gaseous emissions in diesel engines." Energy Sources, Part A: Recovery, Utilization, and Environmental Effects: 1-11.

Fayad, M.A., Fernández-Rodríguez, D., Herreros, J.M., Lapuerta, M., Tsolakis, A., 2018. "Interactions between aftertreatment systems architecture and combustion of oxygenated fuels for improved low temperature catalysts activity." Fuel 229: 189-197.

Fayad, M.A., Herreros, J.M., Martos, F.J., Tsolakis, A., 2015. “Role of Alternative Fuels on Particulate Matter (PM) Characteristics and Influence of the Diesel Oxidation Catalyst.” Environ. Sci. Tech. 49(19): 11967-11973.

Fayad, M.A., Tsolakis, A., Fernández-Rodríguez, D., Herreros, J.M., Martos, F.J., Lapuerta, M., 2017. “Manipulating modern diesel engine particulate emission characteristics through butanol fuel blending and fuel injection strategies for efficient diesel oxidation catalysts." Appl. Energ. 190: 490-500.

Fayad, M.A., Tsolakis, A., Martos, F.J., 2020. "Influence of alternative fuels on combustion and characteristics of particulate matter morphology in a compression ignition diesel engine." Renewable Energy, 149: 962-969.

Fayyazbakhsh, A., Pirouzfar, V., 2016. "Investigating the influence of additives-fuel on diesel engine performance and emissions: Analytical modeling and experimental validation." Fuel, 171: 167-177.

Hardy, W.L., Reitz, R.D., 2006. An experimental investigation of partially premixed combustion strategies using multiple injections in a heavy-duty diesel engine, SAE Technical Paper.

Hotta, Y., Inayoshi, M., Nakakita, K., Fujiwara, K., Sakata, I., 2005. Achieving lower exhaust emissions and better performance in an HSDI diesel engine with multiple injection, SAE Technical Paper.

Hountalas, D.T., Kouremenos, D.A., Pariotis, E.G., Schwarz, V., Binder, K.B., 2004. Investigation concerning the effect of post fuel injection on the performance and pollutants of heavy duty diesel engines using a multi-zone combustion model. Thermoand Fluid Dynamic Processes in Diesel Engines 2, Springer: 257-283.

International, A., 2010. ASTM D975-10-Standard Specification for Diesel Fuel Oils, ASTM International West Conshohocken.

Li, H., Song, C., Lv, G., Pang, H., Qiao, Y., 2017. "Assessment of the impact of post-injection on exhaust pollutants emitted from a diesel engine fueled with biodiesel." Renewable Energy, 114: 924-933.

McCormick, R.L., 2007. "The impact of biodiesel on pollutant emissions and public health." Inhalation Toxicology, 19(12): 1033-1039.

Miri, S.M.R., Seyedi, S.R.M., Ghobadian, B., 2017. "Effects of biodiesel fuel synthesized from non-edible rapeseed oil on performance and emission variables of diesel engines." Journal of cleaner production, 142: 3798-3808.

Miyamoto, N., Ogawa, H., Nurun, N., Obata, K., Arima, T., 1998. Smokeless, low NOx, high thermal efficiency, and low noise diesel combustion with oxygenated agents as main fuel, SAE technical paper.

Mohan, B., Yang, W., Chou, S.K., 2013. "Fuel injection strategies for performance improvment and emissions reduction in compression ignition engines - A review." Renewable and Sustainable Energy Reviews, 28: 664-676. 
Moser, B.R., 2009. "Biodiesel production, properties, and feedstocks." In Vitro Cellular \& Developmental Biology-Plant, 45(3): 229-266.

Nehmer, D.A., Reitz, R.D., 1994. Measurement of the effect of injection rate and split injections on diesel engine soot and NOx emissions, SAE Technical Paper.

Ojeda, W.D., Zoldak, P., Espinosa, R., Kumar, R., 2009. "Development of a fuel injection strategy for partially premixed compression ignition combustion.” SAE International Journal of Engines, 2(1): 1473-1488.

Ozsezen, A.N., Canakci, M., Turkcan, A., Sayin, C., 2008. "Effects of Biodiesel from used frying palm oil on the performance, injection, and combustion characteristics of an indirect injection diesel engine." Energy Fuels, 22: 1297-1305.

Parlak, A., Yasar, H., Hasimoglu, C., Kolip, A., 2005. “The effects of injection timing on NOx emissions of a low heat rejection indirect diesel injection engine.” Appl Therm Eng 25: 3042-3052.

Paul, A., Panua, R., Debroy, D., Kumar Bose, P., 2016. "A performance-emission tradeoff study of a CI engine fueled by compressed natural gas $(\mathrm{CNG}) /$ diesel-ethanol-PPME blend combination.” Environmental Progress \& Sustainable Energy, 35(2): 517-530.

Payri, F., Benajes, J., Arregle, J., Riesco, J.M., 2006. "Combustion and exhaust emissions in a heavy-duty diesel engine with increased premixed combustion phase by means of injection retarding." Oil Gas Sci Technol, 61: 247-258.

Rakopoulos, C.D., Hountalas, D.T., Zannis, T.C., 2004. "Operational and environmental evaluation of diesel engines burning oxygen-enriched intake air or oxygen-enriched fuels: a review." SAE Technical Paper: 01-2924.

Robbins, C., Hoekman, S.K., Ceniceros, E., Natarajan, M., 2011. Effects of biodiesel fuels upon criteria emissions, SAE Technical Paper.

Sayin, C., Canakci, M., 2009. "Effects of injection timing on the engine performance and exhaust emissions of a dual-fuel diesel engine." Energy conversion and management, 50: 203-213.

Shi, L., Xiao, W., Li, M., Lou, L., Deng, K., 2017. "Research on the effects of injection strategy on LTC combustion based on two-stage fuel injection.” Energy, 121: 21-31.

Siddappa, S.B., and M.K. Gajendra Babu, J.P.S., 2007. "Studies on Performance and Exhaust Emissions of a CI Engine Operating on Diesel and Diesel Biodiesel Blends at Different Injection Pressures and Injection Timings." ASAE Techinal Paper: 01-0613, doi:0610.4271/2007-0601-0613.

Standardization, E. C. f., 2004. Automotive Fuels: Fatty Acid Methyl Esters (FAME) for Diesel Engines: Requirements and Test Methods, CEN, European Committe for Standardization.

Sukjit, E., Herreros, J.M., Dearn, K.D., Garcia-Contreras, R., Tsolakis, A., 2012. "The effect of the addition of individual methyl esters on the combustion and emissions of ethanol and butanol -diesel blends." Energy, 42(1): 364-374.

Vanegas, A., Won, H., Felsch, C., Gauding, M., Peters, N., 2008. Experimental investigation of the effect of multiple injections on pollutant formation in a common-rail DI diesel engine, SAE Technical Paper.

Wu, T., Yao, A., Yao, C., Pan, W., Wei, H., Chen, C., Gao, J., 2018. "Effect of diesel late-injection on combustion and emissions characteristics of diesel/methanol dual fuel engine." Fuel, 233: 317-327.

Yamamoto, K., Takada, K., Kusaka, J., Kanno, Y., Nagata, M., 2006. Influence of diesel post injection timing on HC emissions and catalytic oxidation performance. Powertrain and Fluid Systems Conference and Exhibition.

Ye, P., Prabhakar, B., Boehman, A.L., 2013. "Experimental investigation of the impact of post-injection on emissions, combustion and lubricant dilution in a diesel engine with B20 fuel.” International Journal of Engine Research, 14(1): 12-22.

Zhang, Y., Boehman, A.L., 2007. “Impact of biodiesel on NOx emissions in a common rail direct injection diesel engine.” Energy \& Fuels, 21: 2003-2012.

Zheng, Z., Yue, L., Liu, H., Zhu, Y., Zhong, X., Yao, M., 2015. “Effect of two-stage injection on combustion and emissions under high EGR rate on a diesel engine by fueling blends of diesel/gasoline, diesel/n-butanol, diesel/gasoline/n-butanol and pure diesel." Energy conversion and management, 90: 1-11. 